\title{
PENDEKATAN INKLUSI, MENINGKATKAN HASIL BELAJAR TEKNIK LARI SPRINT PELAJAR SMP NEGERI 30 MEDAN
}

\author{
${ }^{1}$ Try Ramonda Tarigan \\ ${ }^{2}$ Sabaruddin Yunis Bangun \\ Correspondence: Universitas Negeri Medan, Medan, Indonesia \\ E-mail:tryramonda@unimed.ac.id, unisbgn@unimed.ac.id
}

\begin{abstract}
Abstrak
Penelitian ini bertujuan untuk mengetahui seberapa besar peningkatan hasil belajar Lari Sprint yang didapat siswa kelas VII SMP Negeri 30 Medan 2017 melalui pendekatan inklusi. Subjek Penelitian ini dilaksanakan di SMP Negeri 30 Medan 2017, sampel dalam penelitian ini adalah siswa kelas VII yang berjumlah 35 orang. Metode penelitian yang digunakan adalah metode penelitian tindakan kelas dengan pendekatan kuantitatif. Untuk memperoleh data dalam penelitian ini maka diadakan tes hasil belajar pada siklus I dan siklus II yang berbentuk melakukan teknik dasar Lari sprint. Hasil tes awal lari sprint melalui pendekatan inklusi yang dilakukan dari 35 siswa terdapat 10 siswa $(28,57 \%)$ yang telah mencapai tingkat ketuntasan belajar dengan nilai rata-rata hasil belajar siswa (60,71). Hasil dari siklus I terdapat 14 siswa (40\%) dari 35 siswa, yang telah mencapai tingkat ketuntasan belajar dengan nilai rata-rata hasil belajar siswa $(66,16)$. Di siklus II terdapat 31 siswa $(88,57 \%)$ dari 35 siswa yang telah mencapai tingkat ketuntasan belajar dengan nilai rata-rata (78,52). Berdasarkan hasil yang didapat maka dapat disimpulkan bahwa Melalui pendekatan inklusi dapat meningkatkan hasil belajar lari sprint pada siswa kelas VII SMP Negeri 30 Medan Tahun Ajaran 2017”.
\end{abstract}

\section{Kata Kunci: Belajar Teknik Lari Sprint, Inklusi}

\section{Pendahuluan}

Pendidikan merupakan suatu kebutuhan yang sangat penting bagi setiap orang. Dalam meningkatkan pendidikan, maka proses pembelajaran merupakan inti yang harus di tingkatkan agar tercapai sesuai dengan tujuan yang sudah di tentukan dalam bentuk terjadinya perubahan tingkah laku, pengetahuan dan keterampilan dalam diri siswa. Tujuan pendidikan tidak akan tercapai bila proses pembelajaran yang diajarkan tidak sesuai rencana pembelajaran yang telah disusun. Berhasil tidaknya pembelajaran salah satu faktor penentunya adalah rencana pembelajaran yang dibuat oleh guru, sebab di dalam rencana pembelajaran guru telah dapat menentukan model pembelajaran yang tepat diberlakukannya untuk siswa.

Atletik merupakan salah satu mata pelajaran yang wajib di berikan kepada siswa sekolah dasar, sekolah menengah pertama, dan sekolah menengah atas, dan bahkan di beberapa perguruan tinggi. Kegiatan olahraga atletik mencakup unsur gerak yang sangat komplek dan geraknya pun semakin lama semakin berpariasi selaras dengan perkembangan ilmu pengetahuan. Gerakan-gerakan yang ada dalam olahraga atletik merupakan gerakan-gerakan dasar pada semua cabang olahraga yang lain, karna olahraga atletik terdapat unsur-unsur jalan, lari, lempar, tolak dan lompat. Cabang olahraga atletik terdiri dari beberapa nomor lari seperti dikemukakan, Syarifuddin Aip (1992) menjelaskan bahwa nomor lari terdiri dari 3 
(tiga) bagian besar yaitu: (1) nomor lain jarak pendek (sprint), (2) nomor lari jarak menengah (middle distance running) dan (3) nomor lari jarak jauh (long distance running).

Berdasarkan hasil pengamatan peneliti sebelumnya megenai proses pembelajaran lari sprint siswa di SMP negeri 30 Medan pada tanggal 14 Maret 2017, ternyata masih banyak siswa yang belum memiliki ketuntasan belajar lari sprint. Siswa juga kurang mengetahui teknik lari sprint yang benar seperti saat melakukan teknik start, teknik lari sprint dan saat melewati garis finish. Nilai KKM pelajaran pendidikan jasmani di SMP negeri 30 Medan adalah 75.

Berikut ini adalah data hasil belajar siswa di SMP negeri 30 Medan pada tanggal 14 Maret 2017 mengenai pembelajaran lari sprint. Dari 35 orang siswa terdiri dari 20 orang putri dan 15 orang putra kelas VII SMP negeri 30 Medan tahun ajaran 2016/2017, ternyata hanya 10 siswa $(28,57 \%)$ yang telah memiliki ketuntasan belajar lari sprint, sedangkan 25 siswa $(71,43 \%)$ yang belum mengerti tentang lari sprint. Nilai KKM pelajaran pendidikan jasmani di SMP negeri 30 Medan adalah 75.

Dari hasil wawancara dengan guru bidang studi penididkan jasmani di sekolah tersebut mengatakan bahwa guru kurang memvariasikan metode dalam melaksanakan pembelajaran. Guru bidang studi dominan menggunakan metode ceramah. Sehingga siswa dapat menjadi jenuh terutama kalau guru tidak pandai menjelaskan. Guru bidang studi juga mengatakan bahwa siswa lebih antusias mengikuti pelajaran praktek daripada pelajaran teori dalam kelas.

Tinggi rendahnya hasil belajar pendidikan jasmani tergantung pada proses pembelajaran yang dihadapi oleh siswa. Dalam pembelajaran pendidikan jasmani, guru menguasai materi yang diajarkan dan cara penyampaiannya. Cara penyampaian pelajaran sering disebut gaya mengajar merupakan faktor yang penting diperhatikan oleh seorang guru. Cara penyampaian pelajaran dengan satu arah akan membingungkan siswa, karena siswa akan menjadi pasif (bersifat manerima saja) tentang apa yang dipelajarinya, sehingga proses belajar pendidikan jasmani menjadi membosankan. Hal ini menyebabkan siswa hanya menjadikan olahraga lari sprint sekedar pelepas kebosanan dalam belajar sehingga penguasaan teknik lari sprint belum dilaksanakan dengan benar.

Untuk itu, peneliti menggunakan gaya inklusi merupakan salah satu metode yang tepat, karena peneliti ingin melihat perkembangan kemampuan siswa dalam proses belajar lari sprint. Pendekatan mengajar inklusi bertujuan untuk melibatkan semua siswa, menyesusaikan perbedaan individu, memberi kesempatan untuk memulai tugas pada tingkat kemampuan sendiri, memberi kesempatan untuk menilai tugas dengan tugas-tugas yang lebih ringan dan dilanjutkan ketingkat tugas yang lebih sulit (berjenjang) sesuai dengan tingkat kemampuan tiap siswa, belajar melihat hubungan antara kemampuan merasa dan tugas yang dapat dilakukan oleh siswa, individualisasi dimungkinkan karena memilih diantara alternatif tingkat tugas yang telah disediakan. Dalam metode ini siswa didorong untuk menentukan tingkat penampilannya dan memungkinkan siswa untuk memperoleh hasil yang lebih baik. 
Tujuan dari penelitian ini adalah untuk meningkatkan hasil belajar teknik lari sprint agar siswa dapat melakukan gerak dasar dengan tepat dan benar melalui penerapan Pendekatan inklusi pada siswa kelas VII SMP Negeri 30 Medan Tahun Ajaran 2016/2017.

Manfaat penelitian adalah sebagai masukan dan informasi bagi guru dan pendidikan jasmani dalam mengatasi kesulitan yang dihadapi siswa dalam melakukan teknik lari sprint, pemanfaatan pendekatan inklusi pada pembelajaran lari sprint.

Pendekatan mengajar inklusi merupakan pendekatan mengajar keempat dari spektrum pendekatan mengajar dari, Amung dan Saputra (2000), tujuan pendekatan mengajar ini untuk membelajarkan siswa pada level kemampuan masing-masing. Setiap siswa harus terlibat dalam proses pembelajaran ini, karena dapat memilih aktivitas yang mereka anggap mampu untuk melakukannya.

Muska Moston (2000) dimana pendekatan mengajar ini memperkenalkan berbagai tingkat tugas. Siswa di beri tugas yang berbeda-berbeda sesuai dengan tingkat kemampuan yang dimiliki, dalam pendekatan ini siswa didorong untuk menentukan tingkat penampilannya dan memberikan kesempatan untuk menganalisis dan sintesis tugas.

Brotosuroyo (1992) "Pendekatan mengajar inklusi merupakan pendekatan mengajar cakupan dengan memperkenalkan berbagai tingkat tugas" Maka gaya mengajar inklusi dapat dicontohkan pada lompat jauh. Jika setiap siswa melakukan percobaan teknik lompat jauh dengan sebanyak 3 kali maka siswa akan mampu berhasil melakukan nya. Akan tetapi keberhasilan itu tidak diperoleh semua siswa dengan tingkat kesulitan yang sama, sebagian siswa dapat melakukannya dengan mudah, sedangkan sebagian lagi harus mengarah kemampuannya untuk dapat melakukan teknik lompat jauh tersebut. Jika jumlah lompatan dinaikkan, maka kesulitannya dalam tugas akan meningkat dan akhirnya akan menyebabkan semakin sidikit jumlah siswa yang akan berhasil dalam penampilannya. Hal ini berarti kita telah memberikan suatu standar tunggal bagi semua siswa, dan banyak siswa yang akan dikeluarkan dengan menaikkan tingkat kesulitan dari tugas tersebut. Jika dibuat kelompok yang berbeda dalam melakukan teknik lompat jauh, dan siswa memilih kelompok yang bisa dilakukannya. Hal ini memungkinkan seluruh siswa untuk menyesuaikan tingkat kemampuannya dengan kemampuan yang dimilikinya.

Rusli Ahmad (2000) bahwa dalam pendekatan ini siswa memilih tingkat performans untuk tiap tugas dan merubahnya sesuai dengan penilain sendiri dari masing-masing terhadap performans itu. Guru memilih tugas itu dan menetapkan bermacam-macam tingkat dari pada tugas itu sesuai dengan tingkat kesulitannya.

Seiring dengan itu, Muska Moston (2000) mengemukakan bahwa, pelaksanaan pendekatan inklusi secara umum: (1) Menjelaskan pendekatan ini kepada siswa. Satu demonstrasi dengan menggunakan tali yang miring akan memberikan ilustrasi yang sangat bagus, (2) siswa disuruh memulai, (3) amati dan memberi waktu bagi siswa untuk melakukan gaya ini, (4) memberi umpan balik kepada siswa tentang peranan siswa dalam pengambilan keputusan dari penampilannya dalam tugas seperti: (a) tanyakan bagaimana mereka memilih 
tugas-tugas, (b) fokuskan perhatian pada penggunaan umpan balik yang netral, agar siswa mengambil keputusan mengenai taraf tugas yang sesuai dengan kemampuannya (c) amati kesalahan-kesalahan dalam penampilan siswa dan kriteria yang menyangkut penampilan dalam tugasnya.

Suprijono (2009), hasil belajar adalah pola-pola perbuatan, nilai-nilai, pengertian-pengertian, sikap-sikap, apresiasi dan keterampilan. Sedangkan, Keller dalam Abdurrahman (2003) mengatakan hasil belajar adalah prestasi aktual yang ditampilkan oleh anak, sedangkan hasil belajar dipengaruhi oleh besarnya usaha yang dilakukan oleh anak didik. Hasil belajar juga dipengaruhi intelegensi dan penguasaan awal anak tentang materi yang akan dipelajari.

Hasil belajar memacu pada terjadinya perubahan tingkah laku pada diri siswa yang dapat diamati dan diukur dalam bentuk perubahan pengetahuan, sikap dan keterampilan. Hasil belajar merupakan indicator untuk mengukur tingkat keberhasilan siswa dalam proses belajar mengajar. Indikator keberhasilan sebagai alat ukur untuk mengetahui tingkat keberhasilan siswa dalam melakukan tindakan belajar.

Sudjana (2009) "penilaian hasil belajar adalah proses pemberian nilai terhadap hasil-hasil belajar yang dicapai siswa dengan kriteria tertentu". Hal ini mengisyaratkan bahwa objek yang dinilainya adalah hasil belajar siswa. Hasil belajar siswa pada hakikat nya adalah perubahan tingkah laku. Tingkah laku sebagai hasil belajar dalam pengertian yang luas mencakup bidang kognitif, efektif dan psikomotoris.

Proses belajar dapat dikatakan efektif bila ada perubahan yang terjadi pada diri siswa setidak tidaknya mencapai tingkat optimal dan efisien dan terletak pada kecepatan dan dikuasinya materi pelajaran yang disajikan, sekalipun dalam waktu yang relatif pendek. Dengan demikian jika gaya dan strategi yang dipilih itu tepat, maka aktifitas proses pembelajaran itu akan produktif, yaitu memberikan hasil yang baik. Oleh sebab itu, penilaian hasil belajar dan proses pembelajaran saling berkaitan satu sama lain sebab hasil merupkan akibat dari proses.

Sutikno (2000) mengemukakan bahwa faktor-faktor yang mempengaruhi proses belajar siswa untuk berhasil ada dua yaitu:

a. Faktor internal yang berasal dari dalam diri siswa itu sendiri, meliputi: Faktor jasmaniah, (kesehatan, cacat tubuh), Faktor psikologis, (intelegasi, perhatian, minat, bakat, motif, kematangan dan kesiapan), Kelelahan.

b. Faktor eksternal yang berasal dari luar peserta didik, meliputi: Keluarga (cara orang tua mendidik, hubungan antar keluarga, suasana rumah, keadaan ekonomi, pengertian orang tua dan latar belakang kebudayaan). Sekolah seperti gaya mengajar, relasi guru dengan peserta didik, kurikulum, relasi antara peserta didik, disiplin, alat pelajaran (media), keadaan gedung, metode belajar, dan tugas rumah). Masyarakat (keadaan peserta didik dalam masyarakat, masyarakat media, teman bergaul, dan bentuk kehidupan masyarakat).

Berkaitan dengan faktor dari dalam diri peserta didik, selain faktor kemampuan, ada juga faktor lain yaitu motivasi, minat, perhatian, sikap, kebiasaan belajar akan memberikan andil yang cukup penting. Berhasil atau 
tidaknya seseorang dalam mencapai hasil belajar disebabkan dari faktor, baik yang berasal dari dalam diri peserta didik maupun yang berasal dari luar dirinya.

Dari penjelasan diatas dapat dikatakan bahwa hasil belajar adalah keseluruhan hasil yang diperoleh dari kegiatan berupa pengetahuan, keterampilan dan sikap yang mampu mengakibatkan perubahan tingkah laku, dimana hasil tersebut dilihat melalui suatu alat ukur yang dinamakan dengan evaluasi.

Hasil belajar adalah akibat dari proses belajar dengan menggunakan alat pengukur yaitu berupa tes yang disusun secara terencana, baik tes tertulis, tes lisan, maupun tes perbuatan, Sujana (2001) dalam Iskandar Wassid (2009). Hasil belajar adalah hasil yang diperoleh siswa setelah mengikuti satu materi tertentu dan mata pelajaran yang berupa data kuantitatif dan kualitatif.

Aip Syarifudin (1992) mengungkapkan bahwa lari jarak pendek adalah semua jenis lari yang sejak dari start sampai finish dilakukan dengan kecepatan maksimal. Sprint atau lari cepat merupakan salah satu nomor lomba dalam cabang olahraga atletik. Sprint atau lari cepat merupakan semua perlombaan lari dimana peserta berlari dengan kecepatan maksimal sepanjang jarak yang ditempuh. Sampai dengan jarak 400 meter masih digolongkan dalam lari cepat atau lari sprint.

Aip Syarifudin (1992) menambahkan pada nomor lari pendek atau sprint ada 3 (tiga) persyaratan yang harus dikuasai oleh seorang pelari, yaitu: (a) teknik start, (b) teknik lari, (c) teknik melewati garis finish. Teknik lari sprint merupakan suatu cara atau kemampuan kemahiran didalam melakukan berbagai unsur gerakan yang berkaitan dengan lari, yaitu sebagai upaya untuk meningkatkan prestasi optimal, seperti diungkapkan, Aip Syarifuddin (1985) bahwa teknik lari jarak pendek: 1) posisi tubuh pada saat lari condong kedepan secara wajar, 2) pada saat lari mulut tertutup dengan rapat serta pandangan ke depan lintasan, 3) ayunan lengan dilakukan dari belakang ke depan secara bergantian dengan siku sedikit dibengkokkan, 4) gerakan langkah kaki panjang dan dilakukan secepat mungkin.

\section{Metode}

Metode penelitian yang digunakan dalam penelitian ini adalah deskriptip dengan jenis penelitian adalah Penelitian Tindakan Kelas (Clasroom Action Research), pendekatan yang digunakan adalah kuantitatif. Pada penelitian tindakan kelas yang memiliki empat tahapan yaitu: (1) Perencanaan, (2) Pelaksanaan, (3) Pengamatan, (4) Refleksi. Adapun instrument penelitian dalam penelitian ini adalah berupa lembar penilaian portofolio tes proses belajar I dan II.

Lokasi penelitian berada di SMP negeri 30 Medan, Penelitian ini dilaksanakan pada semester ganjil selama 2 minggu, dimulai tanggal 18 Mei 2017 sampai 01 Juni 2017. Arikunto (2006) mengatakan bahwa subjek adalah keseluruhan objek peneliti atau objek yang didalamnya terdapat subjek yang dijadikan sumber data yang diharapkan dapatmemberikan data yang dibutuhkan oleh peneliti. Populasi dalam penelitian ini adalah siswa kelas VII SMP Negeri 30 Medan tahun 2017 dengan jumlah siswa sebanyak 67 orang. Sukardi (2003) teknik memilih sampel yang termasuk nonprobabilitas adalah memiliki sampel

PJKR_

http://jurnal.unimed.ac.id/2012/index.php/jpehr/index 
dengan dasar tujuan. Teknik ini juga populer disebut sebagai purposive sampling. Maka sampel dalam penelitian ini adalah kelas VII SMP Negeri 30 Medan dengan jumlah 35 siswa yang terdiri dari 15 putra dan 20 putri.

Analisa data dilakukan dengan 2 cara yaitu reduksi data guna untuk menyeleksi, menyederhanakan dan mentransformasikan data yang telah disajikan dalam transkip catatan lapangan dan memaparkan data berdasarkan lembar portofolio.

\section{Pembahasan}

Berikut ini adalah deskripsi data hasil observasi guru dan siswa pada proses pembelajaran lari sprint di kelas VII SMP Negeri 30 Medan Selayang Tahun Ajaran 2017 yang di ambil dari data tes siklus I dan tes siklus II berikut ini:

Tabel 1. Data Hasil Observasi Guru Pada Proses Pembelajaran Lari Sprint

\begin{tabular}{clcc}
\hline No. & \multicolumn{1}{c}{ Indikator } & Siklus I & Siklus II \\
\hline 1. & Penampilan & 12 & 14 \\
\hline 2. & Membuka Pelajaran & 13 & 14 \\
\hline 3. & Penyajian Materi & 13 & 15 \\
\hline 4. & Proses Interaksi Dengan Siswa & 12 & 15 \\
\hline 5. & Pemanfaatan Media Pembelajaran & 15 & 15 \\
\hline 6. & Mengelola Alat/Bahan & 12 & 14 \\
\hline 7. & Pemberian Umpan Balik & 11 & 13 \\
\hline 8. & Pengaturan Waktu & 14 & 14 \\
\hline 9. & Menutup Pelajaran & 12 & 14 \\
\hline Jumlah & 114 & 128 \\
\hline Rata & rata & 12,66 & $88,88 \%$ \\
\hline Persentase $(\%)$ & $79,16 \%$ & \\
\hline
\end{tabular}

Berdasarkan hasil observasi yang telah dilakukan dalam dua siklus kegiatan pelaksanaan tindakan kelas diperoleh data bahwa aktivitas guru penjas dalam kegiatan pembelajaran mengalami kenaikan. Pada siklus I persentase aktivitas guru 79,16\% sedangkan pada siklus II meningkat menjadi 88,88\%.

Berikut ini adalah deskripsi data hasil observasi partisipasi siswa pada proses pembelajaran lari sprint di kelas VII SMP Negeri 30 Medan Selayang Tahun Ajaran 2017 yang diambil dari data tes siklus I dan tes siklus II berikut ini:

Tabel 2. Data Hasil Observasi Partisipasi Siswa Pada Proses Pembelajaran Lari Sprint

\begin{tabular}{llll}
\hline No. & Indikator & Siklus I & Siklus II \\
\hline 1. & Minat dan Perhatian & 12 & 15 \\
\hline 2. & Kemampuan alat/bahan ajar & 11 & 14 \\
\hline 3. & Keaktifan siswa dalam proses belajar & 12 & 14 \\
\hline 4. & Partisipasi Siswa & 11 & 14 \\
\hline 5. & Kemampuan Bertanya & 11 & 14 \\
\hline Jumlah & 57 & 71 \\
\hline Rata-rata & 11,4 & 14,2 \\
\hline Persentase $(\%)$ & $71,25 \%$ & $88,75 \%$ \\
\hline
\end{tabular}

Berdasarkan hasil observasi yang telah dilakukan dalam dua siklus kegiatan pelaksanaan tindakan kelas diperoleh data bahwa aktifitas atau keaktifan

PJKR_

http://jurnal.unimed.ac.id/2012/index.php/jpehr/index 
siswa dalam mengikuti kegiatan pembelajaran mengalami kenaikan pada siklus I persentase aktifitas $71,25 \%$ sedangkan pada siklus II meningkat menjadi $88,75 \%$.

Berikut ini adalah deskripsi data hasil belajar lari sprint siswa di kelas VII SMP Negeri 30 Medan Selayang Tahun Ajaran 2017 yang diambil dari data tes siklus I dan tes siklus II berikut ini:

Tabel 3. Deskripsi Data Hasil Belajar Lari Sprint

\begin{tabular}{cccccc}
\hline No & Hasil Tes & $\begin{array}{c}\text { Jumlah Siswa } \\
\text { Yang Tuntas }\end{array}$ & $\begin{array}{c}\text { Persentase } \\
(\boldsymbol{\%})\end{array}$ & $\begin{array}{c}\text { Nilai } \\
\text { Rata-Rata }\end{array}$ & Keterangan \\
\hline 1. & Test Siklus I & 14 & $40 \%$ & 66,16 & Tidak Tuntas \\
\hline 2. & Test Siklus II & 31 & $88,57 \%$ & 78,52 & Tuntas \\
\hline
\end{tabular}

Dari data hasil belajar lari sprint yang telah dilakukan dalam dua siklus kegiatan pelaksanaan tindakan kelas diperoleh data bahwa nilai rata-rata siswa juga mengalami kenaikan. Pada siklus I persentase nilai rata-rata yang diperoleh siswa adalah 66,16 sedangkan pada siklus II meningkat menjadi 78,52.

Untuk memudahkan dalam melihat hasil belajar siswa dari siklus I dan silus II secara visual dapat dilihat dari garafik dibawah ini:

Gambar 1. Grafik Ketuntasan dan Nilai Rata-rata Hasil Belajar Siswa

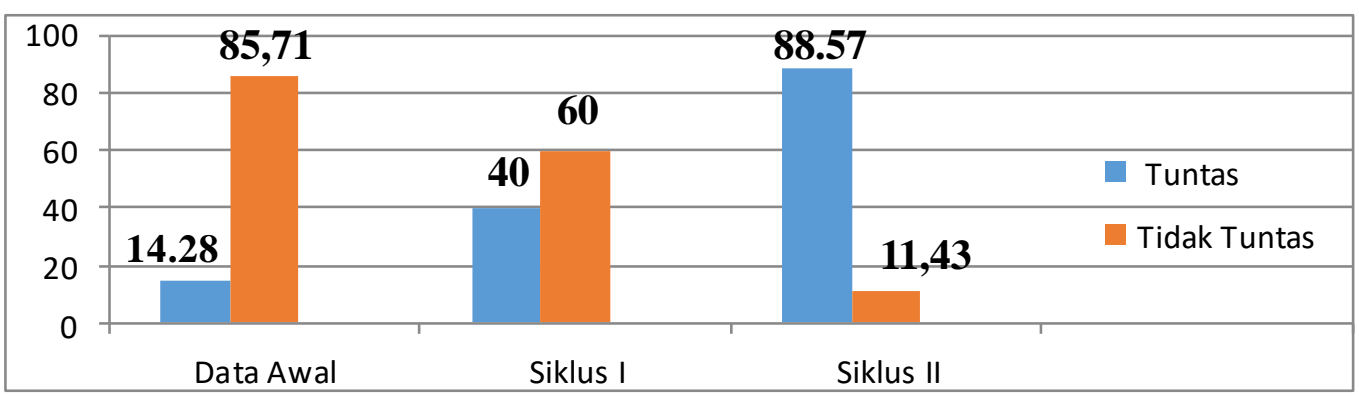

\section{Siklus I}

Berikut ini adalah hasil pelaksanaan siklus I yang telah dilaksanakan. Kegiatan siklus I ini dilakukan peneliti besama dengan guru pendidikan jasmani dalam pembelajaran lari sprint. Pada tahap ini dilakukan observasi terhadap pelaksanaan tindakan yang menggunakan lembar observasi yang telah disusun. Lembar observasi yang telah disusun tersebut terdiri dari lembar observasi guru dan lembar observasi siswa guna mengetahui partisipasi guru dan siswa dalam proses pembelajaran

Berdasarkan hasil observasi yang dilakukan terhadap guru penjas dalam melaksanakan pembelajaran maka dihasilkan sebagai berikut: 1) Dalam kegiatan awal atau membuka pelajaran guru mendapatkan nilai baik, yaitu guru melakukan orientasi, guru melakukan apersepsi, ada usaha guru untuk memotivasi siswa, 2) Dalam penyajian materi guru mendapat nilai baik yaitu menguasai materi yang akan disampaikan kepada siswa, 3) Dalam proses interaksi dengan siswa guru mendapat nilai baik yaitu guru bersikap terbuka kepada siswa, gruru bersikap

PJKR_ 
tegas kepada siswa, guru bersikap objektif, 4) Dalam proses pemanfaatan media pembelajaran guru mendapat nilai sedang yaitu ketersediaan media pembelajaran, kesesuaian media dengan jumlah siswa, 5) Dalam pemberian umpan balik guru mendapat nilai baik yaitu guru dan siswa saling bertanya jawab, memberi kesempatan bagi semua siswa, berkerja sama memecahkan masalah yang kurang dimengerti siswa, 6) Dalam pengaturan waktu guru mendapat nilai cukup yaitu ketepatan memulai pelajaran dan ketepatan waktu menyajikan materi, 7) Dalam menutup pelajaran guru mendapat nilai baik yaitu menyimpulkan materi pelajaran, memberi tugas, menyampaikan manfaat pelajaran.

Dari uraian diatas dapat disimpulkaan bahwa secara keseluruhan dalam kegiatan observasi guru pada siklus I dikategorikan cukup dengan persentase $79,16 \%$.

Berdasarkan hasil observasi yang dilakukan terhadap siswa dalam melaksanakan pembelajaran maka dihasilkan sebagai berikut: 1) Pemahaman terhadap materi yang disampaikan guru mendapat nilai baik, 2) Kemampuan melaksanakan pembelajaran dapat nilai cukup, 3) Keaktifan dalam proses pembelajaran mendapat nilai cukup, 4) Kemapuan dalam bertanya mendapat nilai baik, 5) Partisipasi siswa mendapat nilai sedang

Berdasarkan uraian diatas dapat disimpulkan bahwa secara keseluruhan dalam kegiatan observasi siswa pada siklus I dikategorikan cukup dengan persentase $71,25 \%$.

Capaian yang diberikan pada siklus I sebayak satu kali pertemuan, siswa diberikan tes hasil belajar I yang kemudian diperoleh sebanyak 21 siswa dengan persentase $60 \%$ yang belum mencapai ketuntasan belajar sedangkan 14 orang siswa dengan persentase $40 \%$ yang telah mencapai tingkat ketuntasan belajar. Adapun penjelasan tersebut dapat dilihat dari tabel berikut:

Tabel 4. Data Ketuntasan Hasil Belajar Lari Sprint Tes Siklus I

\begin{tabular}{lllll}
\hline No & Hasil Tes & Keterangan & Jumlah Siswa & Persentase (\%) \\
\hline $\mathbf{1}$ & $<75$ & Tidak Tuntas & 21 & $60 \%$ \\
\hline $\mathbf{2}$ & $\geq 75$ & Tuntas & 14 & $40 \%$ \\
\hline
\end{tabular}

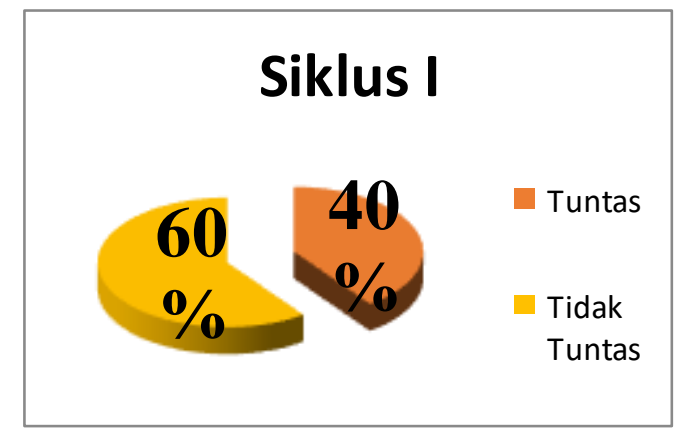

Gambar 2. Grafik Persentase Hasil Belajar lari Sprint (Siklus I)

Berdasarkan tabel diatas dapat dilihat bahwa kemampuan siswa dalam pembelajaran lari sprint dengan menggunakan gaya mengajar pendekatan inklusi ternyata sudah mulai meningkat. Hal ini terlihat dari jumlah siswa yang sudah tuntas dalam belajar semakin meningkat sebanyak 4 orang. Pada siklus I ini jumlah siswa yang sudah tuntas menjadi 14 orang siswa (40\%) dan 21 orang siswa $(60 \%)$ yang belum tuntas dalam belajar. 
Memperhatikan tabel diatas dapat diihat bahwa hasil belajar lari sprint bawah pada siklus I ternyata hasilnya lebih baik dari tes awal namun hasilnya belum cukup maksimal, sehingga perlu dilakukan siklus II. Hal ini dilihat dari masih banyaknya siswa yang kurang tepat dalam melakukan sikap start, sikap saat berlari dan sikap saat finish.dan nilai rata-rata yang diperoleh masih perlu ditingkatkan. Maka solusi yang tepat untuk mengatasinya adalah: 1) Guru menjelaskan secara lebih mendalam tentang gaya mengajar pendekatan inklusi yang diterapkan, 2) Guru meningkatkan pengelolaan kelas agar proses pembelajaran semakin efektif, 3) Guru mengarahkan siswa agar lebih teliti dalam melakukan lari sprint agar nantinya tidak terjadi kesalahan yang sama.

Untuk itu, maka perlu perbaikan tindakan untuk siklus II sesuai dengan solusi yang telah diberikan pada hasil siklus I sehingga memungkinkan peningkatan hasil belajar siklus II.

\section{Siklus II}

Pelaksanaan siklus II diawali dengan Perencanaan, Pelaksanaan, Observasi dan dikahir dengan Refleksi. Berikut ini akan dijelaskan pelaksanaan siklus II. Berdasarkan hasil observasi yang dilakukan terhadap guru penjas dalam melaksanakan pembelajaran maka dihasilkan sebagai berikut: 1) Dalam kegiatan awal atau membuka pelajaran guru mendapatkan nilai baik, yaitu guru melakukan orientasi, guru melakukan apersepsi, ada usaha guru untuk memotivasi siswa, 2) Dalam penyajian materi guru mendapat nilai baik yaitu menguasai materi yang akan disampaikan kepada siswa, 3) Dalam proses interaksi dengan siswa guru mendapat nilai baik yaitu guru bersikap terbuka kepada siswa, gruru bersikap tegas kepada siswa, guru bersikap objektif, 4) Dalam proses pemanfaatan media pembelajaran guru mendapat nilai baik yaitu ketersediaan media pembelajaran, kesesuaian media dengan jumlah siswa, 5) Dalam pemberian umpan balik guru mendapat nilai baik yaitu guru dan siswa saling bertanya jawab, memberi kesempatan bagi semua siswa, berkerja sama memecahkan masalah yang kurang dimengerti siswa, 6) Dalam pengaturan waktu guru mendapat nilai sedang yaitu ketepatan memulai pelajaran dan ketepatan waktu menyajikan materi, 7) Dalam menutup pelajaran guru mendapat nilai baik yaitu menyimpulkan materi pelajaran, memberi tugas, menyampaikan manfaat pelajaran.

Berdasarkan uraian di atas dapat disimpulkan bahwa secara keseluruhan dalam kegiatan observasi guru pada siklus II dikategorikan baik dengan persentase $88,88 \%$. Berdasarkan hasil observasi yang dilakukan terhadap siswa dalam melaksanakan pembelajaran maka dihasilkan sebagai berikut: 1) Pemahaman terhadap materi yang disampaikan guru mendapat nilai baik, 2) Kemampuan melaksanakan pembelajaran dapat nilai baik, 3) Keaktifan dalam proses pembelajaran mendapat nilai baik, 4) Kemapuan dalam bertanya mendapat nilai baik, 5) Partisipasi siswa mendapat nilai sedang

Berdasarkan uraian diatas dapat disimpulkan bahwa secara keseluruhan dalam kegiatan observasi siswa pada siklus II dikategorikan baik dengan persentase $88,75 \%$. Hasil belajar lari sprint pada siklus II dengan penilaian portofolio indikator 1 gerakan saat start rata-ratanya $(3,31)$, indikator 2 gerakan 
sikap saat berlari rata-ratanya $(3,05)$, indikator gerakan saat finish rata-ratanya $(2,94)$. Berdasarkan hasil penilaian portofolio disetiap indikator dari pelaksanaan tindakan siklus II dapat disimpulkan masih ada beberapa siswa yang belum mencapai deskriptor dari indikator tersebut siswa masih kurang paham dengan tahap-tahap pelaksanaan yang diterapkan guru kepada siswa.

Capaian yang diberikan pada tindakan siklus II sebanyak satu kali pertemuan, siswa diberikan tes hasil belajar II yang kemudian diperoleh sebanyak 31 siswa dengan persentase $88,57 \%$ yang telah mencapai ketuntasan belajar sedangkan 4 siswa dengan persentase $11,43 \%$ belum mencapai tingkat ketuntasan yang diharapkan. Adapun penjelasan tersebut dapat dilihat dari tabel 5 di bawah ini:

Tabel 5. Data Ketuntasan Hasil Belajar Lari Sprint Siklus II

\begin{tabular}{lllll}
\hline No & \multicolumn{1}{c}{ Hasil Tes } & \multicolumn{1}{c}{ Keterangan } & \multicolumn{1}{c}{ Jumlah Siswa } & \multicolumn{1}{c}{ Persentase } \\
\hline $\mathbf{1}$ & $<75$ & Tidak Tuntas & 4 & $11,43 \%$ \\
\hline $\mathbf{2}$ & $\geq 75$ & Tuntas & 31 & $88,57 \%$ \\
\hline
\end{tabular}

Gambar 3. Grafik Persentase Hasil Belajar Lari Sprint (Siklus II)

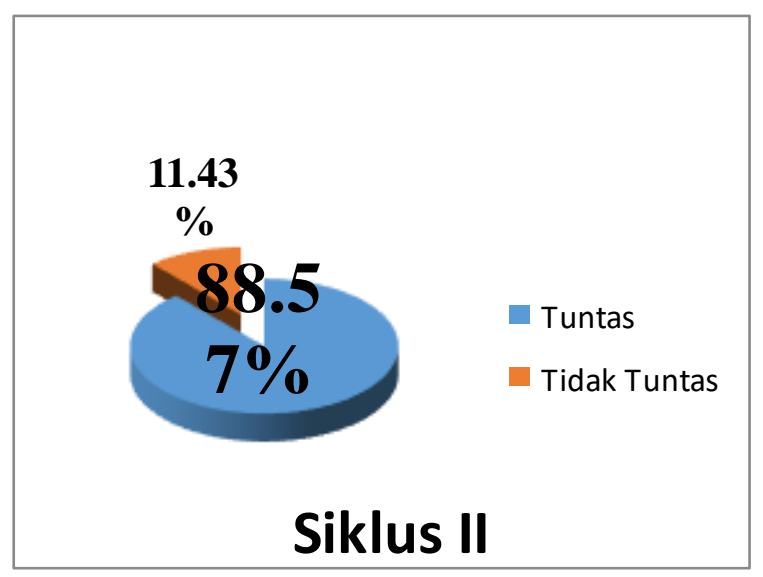

Berdasarkan data diatas dapat dilihat bahwa hasil belajar siswa dalam pembelajaran lari sprint sudah meningkat. Pada siklus II terdapat 31 orang siswa $(88,57 \%)$ yang sudah mencapai nilai ketuntasaan dan hanya 4 orang siswa $(11,43 \%)$ yang belum tuntas dalam belajar. Dari data diatas dapat disimpulkan bahwa hasil belajar lari sprint pada siklus II sudah meningkat dibandingkan dengan siklus I. Peningkatan ketuntasan belajar siswa sudah cukup signifikan dan guru pendidikan jasmani tetap memberikan masukan dan bimbingan selanjutnya.

Hasil belajar pada siklus II ini dapat digunakan sebagai acuan untuk memberikan tindakan pembelajaran pada materi lari sprint dengan menggunakan gaya mengajar pendekatan inklusi bagi guru pendidikan jasmani di SMP Negeri 30 Medan. Adapun kendala yang ditemukan dalam pelaksanaan tindakan siklus II ini adalah sebagai berikut: 1) Siswa yang belum mampu melakukan teknik start dengan baik dan belum menguasai teknik lari yang benar ada $(11,43 \%)$, 2) Dalam pelaksanaan siklus II sebagian besar siswa sudah mampu menguasai teknik dasar lari sprint, namun hanya 4 siswa lagi yang belum tuntas, maka proses pembelajaran lebih ditingkatkan lagi.

Berdasarkan data penelitian yang diperoleh, maka pada penelitian ini memperoleh hasil penelitian sebagai berikut:

\section{Siklus I}

PJKR_

http://jurnal.unimed.ac.id/2012/index.php/jpehr/index 
Hasil siklus I menunjukkan bahwa ketuntasan belajar lari sprint siswa sudah mulai meningkat. Maka dengan peningkatan tersebut dapat ditarik sebuah kesimpulan bahwa proses pembelajaran lari sprint dengan menggunakan gaya mengajar pendekatan inklusi yang dilaksanakan oleh guru dapat mempengaruhi proses belajar mengajar lari sprint pada siswa kelas VII SMP Negeri 30 Medan Tahun Ajaran 2017.

Dari hasil data pada siklus I masih terdapat beberapa siswa yang belum memahami teknik ataupun cara melakukan lari sprint dengan benar sehingga masih ada siswa yang belum tuntas dalam belajar. Salah satu gerakan yang masih memerlukan perbaikan yaitu gerakan ayunan tangan saat belari yang terlalu rendah ayunannya sehingga saat berlari tidak terlalu baik ayunan tangan dan langkah kaki. Kesalahan tersebutlah yang menyebabkan beberapa siswa yang belum tuntas dalam melakukan lari sprint. Hal ini terlihat bahwa siswa yang tuntas sebanyak 14 siswa (40\%) dan siswa yang tidak tuntas sebanyak 21 siswa (60\%). Hal inilah yang menyebabkan masih perlu dilakukan tindakan siklus II.

Berdasarkan hasil penelitian pada kegiatan awal, kegiatan lanjutan siklus I dalam proses pembelajaran lari sprint, ternyata telah diperoleh peningkatan hasil belajar yang signifikan. Tes awal yang diberikan kepada siswa berupa tes keterampilan lari sprint yang dilakukan sebelum menentukan perencanaan berguna untuk mengetahui perkembangan hasil belajar sebelum diadakan pembelajaran lari sprint dengan menggunakan gaya mengajar pendekatan inklusi.

\section{Siklus II}

Pada pelakasanaan siklus II, sebagian besar siswa telah mampu melakukan lari sprint dengan baik. Siswa sudah melakukan sesuai dengan yang diinstruksi oleh guru penjas. Hal ini menunjukkan bahwa guru telah melakukan pengelolaan kelas dan pelaksanaan kegiatan belajar dengan baik.

Berdasarkan hasil penelitian diketahui bahwa sampai pada siklus ke II telah tercapai ketuntasaan belajar lari sprint siswa SMP Negeri 30 Medan Tahun Ajaran 2017. Ketuntasan belajar telah mencapai KKM yaitu 75. Selain itu pada siklus II ini dari 35 subjek dalam penelitian ini, ternyata telah 31 siswa $(88,57 \%)$ yang telah memiliki ketuntasan belajar.

\section{Simpulan}

Dari hasil penelitian ini dapat ditarik kesimpulan bahwa penerapan hasil belajar dengan menggunakan gaya mengajar pendekatan inklusi pembelajaran dapat meningkatkan hasil belajar lari sprint mulai dari sikap saat start, saat berlari, serta gerakan saat finish. Penerapan gaya mengajar pendekatan inklusi sangat berperan dalam meningkatkan kemampuan siswa dalam melakukan rangkaian lari sprint.

Meningkatkan hasil belajar lari sprint pada siswa kelas VII SMP Negeri 30 Medan Tahun Ajaran 2017. Hal ini dapat dilihat pada siklus I hasil belajar yang diperoleh sebanyak 14 orang siswa (40\%) yang tuntas dalam belajar dan 21 orang siswa $(60 \%)$ yang belum tuntas dalam belajar. Sedangkan pada siklus II terdapat peningkatan yang sangat signifikan, yaitu 31 orang siswa $(88,57 \%)$ yang sudah 
tuntas dalam belajar dan hanya 4 orang siswa $(11,43 \%)$ yang tidak tuntas dalam belajar. Peningkatan hasil belajar dari siklus I ke siklus II adalah sebesar 48,57 \%.

\section{Rujukan}

Abdurrahman, 2003. Proses Belajar dan Mengajar. Bandung: Penerbit Erlangga Aip Syarifuddin, 1997. Olahraga Pilihan Atletik. Jakarta: Depdikbud, Dikti, Proyek Pembinaan Tenaga Kependidikan

Amung, Saputra, 2000. Perkembangan Gerak dan Belajar Gerak. Jakarta: Departemen Pendidikan Nasional

Brotosuryo, Mosston, 1992. Colombus Charles end merril publishing company

Mosston, Muska, 2000. Teaching Physical Education, Diterjemahkan Oleh Sudjarwo dan Furqon, Program Pascasarjana Universitas Sebelas Maret. Surakarta

Rusli Lutan, 2000. Strategi Belajar Mengajar Pendidikan Jasmani dan Kesehatan. Departemen Pendidikan Nasional. Jakarta: Derektoriat Jendral Pendidikan Dasar dan Menengah. Bagian Proyek Penataran Guru SLTP Setara D- III

Sudjana, Nana, 2002. Metoda Statistik, Bandung: Penerbit Tarsito

Suharsimi Arikunto, 2010. Prosedur Penelitian (suatu pendekatan praktek). Edisi Revisi V. Jakarta: Bumi Aksara

Sudjana, Nana, 2009. Penilaian Hasil Proses Belajar Mengajar. Bandung: PT. Remaja Rosdakarya

Sukardi, 2003. Metodologi penelitian pendidikan kompetensi dan praktiknya. Jakarta: PT. Raja Grafindo Persada

Suprijono, 2009. Proses Belajar dan Mengajar. Bandung: Penerbit Erlangga

Sutikno, Sobry, 2000. Belajar dan Pembelajaran. Bandung: Prospect 